\title{
PHENOLOGY, GROWTH, AND YIELD OF FIELD-GROWN SOYBEAN AND BUSH BEAN AS A FUNCTION OF VARYING MODES OF N NUTRITION
}

\author{
J. E. THIES,* P. W. SINGLETON and B. B. BOHLOOL+ \\ University of Hawaii NifTAL Project, 1000 Holomua Avenue, Paia, HI 96779, U.S.A.
}

\begin{abstract}
Summary-In field trials conducted at four sites in Hawaii, soybean (Glycine max) and bush bean (Phaseolus vulgaris) were either inoculated with homologous rhizobia, fertilized at high rates with urea, or left unamended. Crop phenology was assessed every few days. Rates of biomass and $\mathrm{N}$ accumulation and components of yield were measured five times during each crop cycle to assess the extent to which: (i) crops relying on soil, symbiotic, or fertilizer $\mathrm{N}$ differed in their growth characteristics; (ii) mode of $\mathrm{N}$ nutrition affected the timing of developmental stages; and (iii) effects of $\mathrm{N}$ nutrition on crop growth and development were related to final yield. While all measured variables differed significantly between sites, the effect of changing $\mathrm{N}$ source on these variables, in $\mathrm{N}$ limited environments, was consistent across sites. Rate and extent of node production, crop growth and yield were increased in symbiotic and $\mathrm{N}$-fertilized crops as compared to unamended, non-fixing crops, while reproductive development was protracted. Extended time required to reach reproductive maturity was attributable to an increase in seed fill duration as time to flowering was not affected. Development and yield of $\mathrm{N}_{2}$-fixing crops were similar but not equivalent to those of $\mathrm{N}$-fertilized crops. To produce reliable yield estimates, legume growth simulation models must be able to accurately simulate crop growth and phenology. The present data indicate that information relating to source and supply of $\mathrm{N}$ must be incorporated before such models can be used to generate reliable yield estimations. Results of these trials also provide a valuable dataset for calibrating model subroutines for inorganic nitrogen uptake and nitrogen fixation in soybean and bush bean growth under field conditions and adjusting model coefficients for tropical environments.
\end{abstract}

\section{INTRODUCTION}

Soybean (Glycine max) and bush bean (Phaseolus vulgaris) are two economically important grain legumes that are grown in diverse environments throughout the world. Both form a symbiotic relationship with the $\mathrm{N}$,-fixing bacteria Bradyrhizobium japonicum and Rhizobium leguminosarum bv. phaseoli, respectively. While yield of symbiotic plants may often be comparable to that of $\mathrm{N}$ fertilized plants (Summerfield et al., 1977; Imsande, 1989; Kucey, 1989), plants relying on fixed $\mathrm{N}$ for growth may achieve only $80-90 \%$ of the yield possible with $\mathrm{N}$ fertilization (Silsbury, 1977; Ryle et al., 1979; Thies et al., 1991). Yield of symbiotic bush bean in particular is frequently observed to be lower than that of $\mathrm{N}$ fertilized plants (Graham, 1981; Thies et al., 1991).

The metabolic cost of $\mathrm{N}$ assimilation via $\mathrm{N}_{2}$ fixation is higher than that for root uptake primarily due to the high energy requirement of the nitrogenase enzyme and ancillary costs involved in developing and maintaining nodule tissue (Imsande, 1988; Lynch and Wood, 1988; Pate and Layzell, 1990). In fact, the

* Present address for correspondence: Centre for Legumes in

Mediterranean Agriculture (CLIMA), The University of

Western Australia, Nedlands, WA 6009, Australia.

+ Deceased minimum theoretical biological cost of $\mathrm{N}$ assimilation via $\mathrm{N}_{2}$ fixation has been estimated to be as much as $36 \%$ greater than that for N03 uptake and reduction (Pate and Layzell, 1990). This additional energy requirement of symbiotic plants may then result in differences in developmental and growth rates due to the diversion of energy to fix $\mathrm{N}_{2}$ that might otherwise have been used for other growth processes. In $\mathrm{N}$ deficient soils, however, this cost would be amortized against the obvious benefits derived from obtaining fixed $\mathrm{N}$.

Nitrogen is an essential element in numerous cell constituents. Consequently, the effects of $\mathrm{N}$ deficiency on crops are dramatic. In general, $\mathrm{N}$ deficiency causes a reduction in growth rate, general chlorosis, often accompanied by early senescence of older leaves, and reduced yield. In the case of legumes, non-nodulated, presumably $\mathrm{N}$ restricted plants, also mature earlier than their nodulated counterparts (Weber, 1966; George et al., 1990).

Numerous models exist that use legume crop phenology to predict yield under varying environmental conditions. Some of these models (Sinclair and de Wit, 1976; Sinclair, 1986) place primary emphasis on nitrogen nutrition, especially on relationships between mobilized $\mathrm{N}$ and currently fixed $\mathrm{N}$, while other models, some of which are used worldwide, do not 
model $\mathrm{N}$ nutrition and hence must assume that plants are well-nodulated and have sufficient $\mathrm{N}$ for maximum growth under a given set of climatic conditions (Hodges and French, 1985; Jones et al., 1989). This assumption is not an issue if growth and yield predictions are to be made for crops grown under fertile conditions where sufficient populations of effective, homologous rhizobia are present. However, for these models to be of broader applicability and to address satisfactorily the problems common to crop production in the Developing World, the effects of nutrient insufficiencies, particularly $\mathrm{N}$, on crop growth should be evaluated.

Our work was undertaken to investigate how mode of $\mathrm{N}$ nutrition effects growth, development, and yield of soybean and bush bean under tropical field conditions and to provide input data for calibration (or validation) of nitrogen subroutines in legume crop growth simulation models.

\section{MATERIALS AND METHODS}

Diverse, well-characterized, fully instrumented sites (Soil Conservation Service, 1984 [MauiNet]) were selected and planting dates varied to provide differences in both temperature and photoperiod in order to establish whether any differences in development caused by mode of $\mathrm{N}$ nutrition were independent of location and climatic effects and to provide wide environmental variation for model input.

\section{Field inoculation trials}

The effects of mode of $\mathrm{N}$ nutrition on crop phenology, biomass and $\mathrm{N}$ accumulation, and seed yield of soybean [G. $\max$ (L.) Merr. cv. Clark IV, nodulating and non-nodulating isolines] and bush bean [P. vulgaris (L.) cv. Bush Bountiful] were assessed in field trials conducted at four sites on Maui, Hawaii, during 1987 and 1988 (Table 1). Crops were either: (i) grown uninoculated, without applied $\mathrm{N}$; (ii) inoculated at planting with an equal mixture of three homologous strains of rhizobia in a

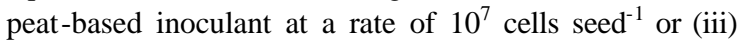
fertilized with urea at a rate of $100 \mathrm{~kg} \mathrm{~N}^{-1}$ week $^{-1}$ from emergence to physiological maturity (R7). Total $\mathrm{N}$ applied in treatment (iii) equaled $700-1200 \mathrm{~kg} \mathrm{~N} \mathrm{ha}^{-1}$ depending upon the time to reach physiological maturity. Crops were planted in a split-plot design with legume species assigned to mainplots and $\mathrm{N}$ source treatments confined to subplots. There were four replications. Soil amendments, planting density, inoculation procedures, enumeration of indigenous rhizobial populations, and early ( $\mathrm{R} 2$, full-bloom) and final ( $\mathrm{R} 8$, grain maturity) harvest procedures have been described by Thies et al. (1991). In these trials, additional biomass harvests were performed at growth stages: V4 (four nodes on the main stem); R5/R6 (mid pod-fill); and R7 (physiological maturity) at sites I, 2 and 3 (Table 1). For each plot, plants were cut at the soil surface from $3.0 \mathrm{~m}$ of a linear row (1.8 $\mathrm{m}^{2}$ ) for the
V4 and R5/R6 harvests and from $4.5 \mathrm{~m}$ of a linear row $\left(2.7 \mathrm{~m}^{2}\right)$ for the $\mathrm{R} 7$ harvest. Fresh weight of the sample was determined immediately. A subsample of 10-15 plants was taken to determine moisture and $\mathrm{N}$ content. A five plant subsample was taken for determination of leaf area and dry weight of component parts. Fresh weight of both subsamples was taken in the field and average number of nodes on the main stem (V stage) recorded. The larger subsamples from all plots were dried, weighed, ground, and analyzed for $\mathrm{N}$ content as described by Thies et al. (1991). Leaves were removed from plants in the smaller subsamples and leaf area determined with a Licor LI-3100 leaf area meter. Leaves and stems were dried at $70^{\circ} \mathrm{C}$ to constant weight and weighed separately.

\section{Crop phenology and growth analysis}

Crop phenology was recorded every few days in the field from emergence (VO) to physiological maturity (R7) according to the stage of development descriptions of Fehr et al. (1971). Crop growth rate (CGR) and nitrogen assimilation rate (NiAR) were calculated by dividing the net increase in biomass or $\mathrm{N}$ assimilated by the number of days between harvests. Leaf weight ratio (LWR) equalled leaf dry weight divided by total shoot dry weight. Specific leaf area (SLA) was calculated by dividing leaf area $\left(\mathrm{cm}^{2}\right)$ of the subsample by its leaf dry weight $(\mathrm{g})$. Total leaf dry weight (Lw) $\left(\mathrm{g} \mathrm{m} \mathrm{m}^{-2}\right.$ was determined by multiplying dry weight of above ground biomass by LWR. Leaf area index (LAI) was calculated by multiplying Lw by SLA and dividing by 10,000 . Seed fill duration was calculated as days to R7 minus days to R4 (Fehr et al., 1971). Growing degree days (GDD) were determined by taking the sum from sowing to first flower and from sowing to physiological maturity of the mean daily air temperature minus a base temperature of $7.8^{\circ} \mathrm{C}$ (Hadley et al., 1984).

\section{Additional data collected}

All sites were instrumented to record air temperature, soil temperature at 10 and $50 \mathrm{~cm}$ depth, precipitation and solar radiation. Total soil $\mathrm{N}(\%)$ and soil $\mathrm{N}$ mineralization potential (by both aerobic and anaerobic methodologies) in unamended field soil were measured prior to planting.

\section{Data analysis}

All crop growth data were analyzed using the analysis of variance (ANOVA) procedures of PCSAS (SAS Institute, 1986). Data were analyzed first by site then were subjected to combined analysis (McIntosh, 1983) across sites to evaluate main effects of site and associated interactions.

\section{RESULTS}

Modes of $\mathrm{N}$ nutrition were defined as: (i) soil $\mathrm{N}$ uptake only, unamended; (ii) soil $\mathrm{N}$ uptake plus nitrogen fixation, symbiotic; and (iii) soil $\mathrm{N}$ plus urea 
Table 1. Elevation, planting date, days to first flower (R1), growing degree days and daylength at Rl, average soil and air temperature during crop growth of soybean and bush bean, and total soil $\mathrm{N}$ at four field sites on Maui, Hawaii

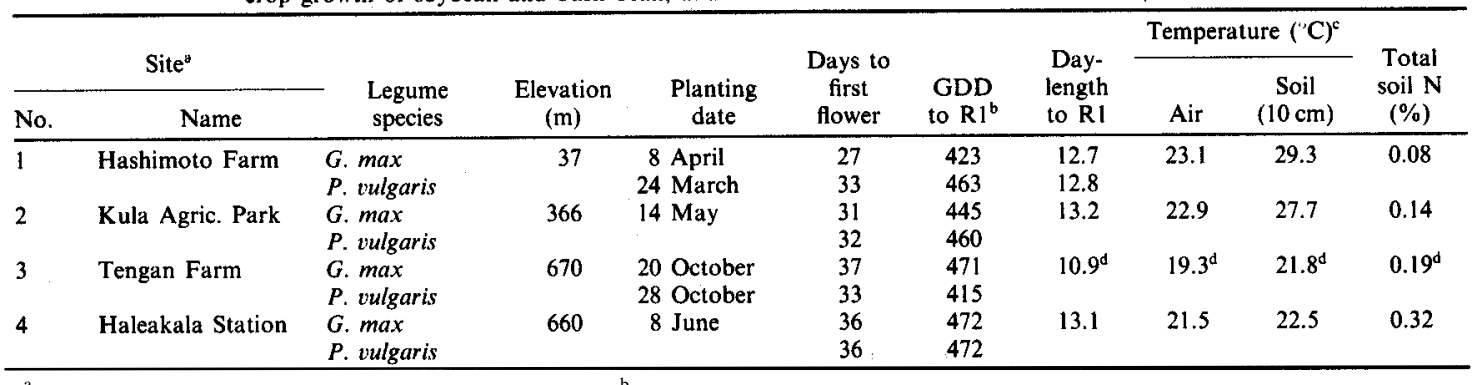

${ }^{\mathrm{a}}$ For more detailed site descriptions see Thies tal. (1991). ${ }^{\mathrm{b}}$ Growing degree days calculated

using a base temperature of $7.8^{\circ} \mathrm{C}$ (Hadley $\mathrm{eal}$., 1984). ${ }^{\mathrm{c}}$ From sowing to physiological maturity

fsoybean at each site. ${ }^{\mathrm{d}}$ From Pulehu Farm (MauiNet) weather station located $0.75 \mathrm{~km}$

north.

fertilizer $\mathrm{N}$ uptake, $\mathrm{N}$ fertilized. The effect of mode of $\mathrm{N}$ nutrition on crop phenology, growth, and components of yield of soybean and bush bean was evaluated in four different environments (Table 1). For soybean, only inoculated plants were symbiotic as a non-nodulating isoline was used in the unamended and $\mathrm{N}$ fertilized treatments and B. japonicum was absent at all sites. Low numbers of indigenous R. leguminosarum bv. phaseoli were present at all sites. Therefore, uninoculated, unfertilized bush bean plants were at least partially symbiotic. However, the rate of applied $\mathrm{N}$ was sufficient to inhibit nodulation by indigenous rhizobia on this species in the fertilizer $\mathrm{N}$ treatment.

Soil $N$ availability and proportional dependence on nitrogen fixation

Nitrogen accumulation by nonnodulating, unamended soybean provided a direct measure of soil $\mathrm{N}$ available for crop growth in these trials, a means by which to estimate the proportion of $\mathrm{N}$ derived from fixation (Ndfa) in nodulated soybean, and a means by which to estimate the proportion of $\mathrm{N}$ derived from fertilizer (Ndff) in $\mathrm{N}$ fertilized soybean across the crop cycle (Fig. 1). Soil $\mathrm{N}$ supply in relation to crop $\mathrm{N}$ demand was low at sites 1, 2 and 4 as evidenced by the low amount of $\mathrm{N}$ accumulated by nonnodulating, unamended soybean, whereas, available soil $\mathrm{N}$ at site 3 continued to support $\mathrm{N}$ accumulation in this treatment throughout reproductive growth. Nodulated soybeans were primarily dependent on $\mathrm{N}_{2}$ fixation for their $\mathrm{N}$ nutrition at sites 1, 2 and 4 where 82,76 and $58 \%$, respectively, of $\mathrm{N}$ accumulated was derived from $\mathrm{N}_{2}$ fixation by grain maturity. This compares to only $16 \% \mathrm{Ndfa}$ for plants grown at site 3 . In $\mathrm{N}$ fertilized soybean, the proportion of $\mathrm{N}$ derived from fertilizer was 82, 78, 39 and $69 \%$ at sites $1,2,3$, and 4 , respectively.

\section{Effect of mode of $N$ nutrition on crop phenology}

While there were significant differences between both sites and species in days to full-bloom (R2), there was no apparent effect of $\mathrm{N}$ treatment on flowering (R1/R2) in either legume (Table 2). For soybean, observed differences in the time of flowering between sites were likely due to temperature differences as a strong correlation was observed between time of flowering and growing degree days $(r=0.98, \mathrm{P}=$ 0.006) (Table 1).

Differences in reproductive phase duration between $\mathrm{N}$ source treatments in soybean were evident by $\mathrm{R} 4$ at sites 1, 2 and 4 (Table 2). In general, the duration of each successive phase was slightly

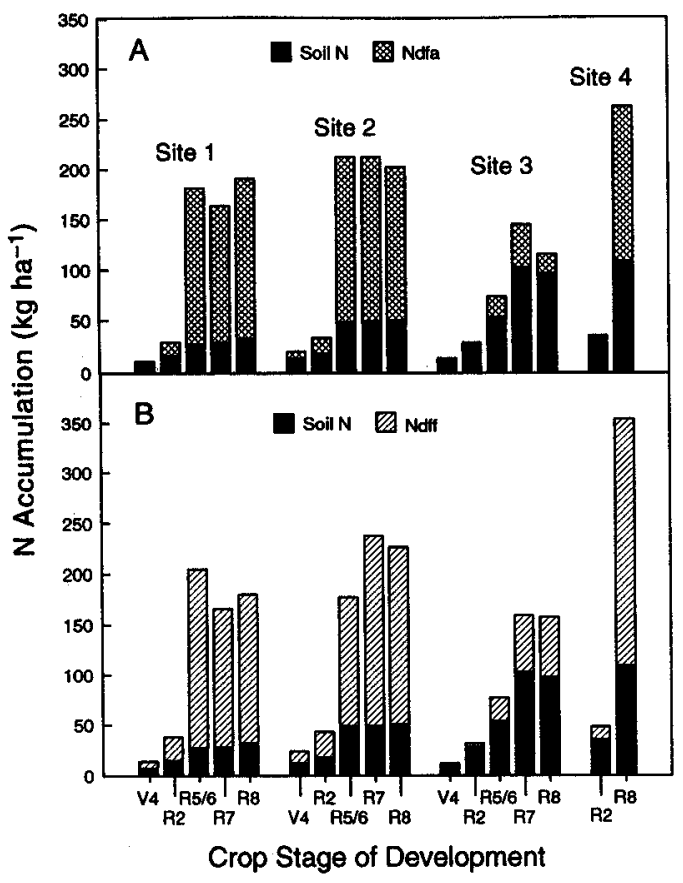

Fig. 1. Nitrogen accumulated by nonnodulating, unamended soybean (soil N) and (A) nodulated (inoculated) soybean; and (B) N fertilized soybean grown at four sites on Maui, Hawaii. Nitrogen derived from fixation (Ndfa) by nodulated soybean is represented by the increase in $\mathrm{N}$ accumulation over nonnodulating, unamended plants in panel (A). Nitrogen derived from fertilizer (Ndff) by $\mathrm{N}$ fertilized soybean is represented by the increase in $\mathrm{N}$ accumulation over nonnodulating, unamended plants in panel (B). 
Table 2. Average days to critical phenological stages in soybean and bush bean grown under three modes of $N$ nutrition at four sites on Maui, Hawaii

\begin{tabular}{|c|c|c|c|c|c|c|c|c|c|}
\hline \multirow{2}{*}{$\begin{array}{l}\text { Legume } \\
\text { species }\end{array}$} & \multirow{2}{*}{$\begin{array}{l}\text { Site } \\
\text { No. }\end{array}$} & \multirow{2}{*}{$\begin{array}{l}\text { N source } \\
\text { treatment }\end{array}$} & \multicolumn{6}{|c|}{ Phenological stage (days) } & \multirow{2}{*}{$\begin{array}{l}\text { Seed fill } \\
\text { duration }\end{array}$} \\
\hline & & & V4 & R2 & R4 & R6 & R7 & R8 & \\
\hline \multirow[t]{12}{*}{ G. $\max$} & \multirow[t]{3}{*}{1} & Unamended & 28 & 30 & 43 & 58 & 70 & 84 & 27 \\
\hline & & Inoculated & 27 & 30 & 43 & 58 & 80 & 90 & 37 \\
\hline & & N Fertilized & 26 & 30 & 45 & 62 & 82 & 90 & 37 \\
\hline & \multirow[t]{3}{*}{2} & Unamended & 31 & 34 & 42 & 60 & 75 & 92 & 33 \\
\hline & & Inoculated & 30 & 34 & 44 & 67 & 81 & 96 & 37 \\
\hline & & N Fertilized & 29 & 34 & 46 & 67 & 84 & 99 & 38 \\
\hline & \multirow[t]{3}{*}{3} & Unamended & 34 & 41 & 47 & 81 & 93 & 109 & 46 \\
\hline & & Inoculated & 34 & 41 & 47 & 86 & 94 & 109 & 47 \\
\hline & & N Fertilized & 34 & 41 & 47 & 85 & 99 & 113 & 52 \\
\hline & \multirow[t]{3}{*}{4} & Unamended & 31 & 38 & 48 & 74 & 89 & 106 & 41 \\
\hline & & Inoculated & 31 & 38 & 47 & 74 & 93 & 108 & 46 \\
\hline & & N Fertilized & 30 & 38 & 53 & 82 & 99 & 113 & 46 \\
\hline \multirow[t]{12}{*}{ P. vulgaris } & \multirow[t]{3}{*}{1} & Unamended & 28 & 35 & 39 & 56 & 63 & 69 & 24 \\
\hline & & Inoculated & 29 & 35 & 39 & 56 & 64 & 69 & 25 \\
\hline & & N Fertilized & 24 & 35 & 40 & 63 & 69 & 73 & 29 \\
\hline & \multirow[t]{3}{*}{2} & Unamended & 26 & 34 & 40 & 53 & 56 & 72 & 16 \\
\hline & & Inoculated & 25 & 34 & 40 & 53 & 59 & 74 & 19 \\
\hline & & N Fertilized & 24 & 34 & 40 & 53 & 65 & 78 & 25 \\
\hline & \multirow[t]{3}{*}{3} & Unamended & 28 & 35 & 39 & 59 & 82 & 97 & 43 \\
\hline & & Inoculated & 28 & 35 & 38 & 59 & 82 & 99 & 44 \\
\hline & & N Fertilized & 28 & 35 & 39 & 59 & 82 & 98 & 43 \\
\hline & \multirow[t]{3}{*}{4} & Unamended & 30 & 38 & 43 & 53 & 65 & 83 & 22 \\
\hline & & Inoculated & 30 & 38 & 42 & 53 & 68 & 85 & 26 \\
\hline & & N Fertilized & 30 & 38 & 43 & 53 & 70 & 90 & 27 \\
\hline
\end{tabular}

a Period from R4 to R7 (Fehr et al, 1971).

extended in $\mathrm{N}$ fertilized soybean compared to unamended plants. This resulted in increased seed fill duration which delayed reproductive maturity and significantly extended duration of crop growth in the fertilizer $\mathrm{N}$ treatment at all sites. Increased seed fill duration and delayed reproductive maturity in inoculated plants were observed at all sites except ste 3 . However, differences in phase duration between these and unamended plants did not occur until the later phases of reproductive development (generally between R6 and R7).

Differences in phase duration due to mode of $\mathrm{N}$ nutrition also occurred during the later reproductive phases in bush bean (Table 2). With the exception of site 3, duration of crop growth of $\mathrm{N}$ fertilized bush bean was significantly extended over that of both inoculated and uninoculated plants. No significant difference in duration of crop growth between inoculated and uninoculated bush bean was observed at any site. There were, however, indigenous R. leguminosarum bv. phaseoli present at all sites and, at sites 2 and 3, nodule mass at R2 on uninoculated plants was not significantly different from that on inoculated plants (Thies et al., 1991). Nodule mass was significantly increased by inoculation at sites 1 and 4, but increased nodulation did not significantly increase $\mathrm{N}$ accumulation.

\section{Effect of mode of $N$ nutrition on vegetative development} and components of yield

Differences in vegetative growth between $\mathrm{N}$ source treatments in both crops were apparent by full bloom (R2) when the rate of leaf appearance in $\mathrm{N}$ fertilized plants was as much as $29 \%$ greater than that in unamended plants (Table 3). For soybean, $\mathrm{N}$ fertil- ized plants had $37-60 \%$ greater node production by physiological maturity than unamended, nonnodulating plants. Leaf production by symbiotic soybean was $22-40 \%$ greater than that of unamended plants, but $5-14 \%$ lower than that of $\mathrm{N}$ fertilized plants. While symbiotic soybeans were similar in vegetative developmental pattern to $\mathrm{N}$ fertilized plants, they were not strictly equivalent. Node production in bush bean was also influenced by mode of $\mathrm{N}$ nutrition. At sites where $\mathrm{N}$ was limiting yield, $\mathrm{N}$ fertilized plants consistently produced one additional node on the main stem as compared with uninoculated plants. Inoculated plants also produced an additional node on the main stem as compared to uninoculated plants at sites 1 and 4 . Consistent with its growth habit, no additional node production occurred after R4 in bush bean.

No significant $\mathrm{N}$ source treatment effect on vegetative development was observed for either soybean or bush bean grown at site 3 , however, available soil $\mathrm{N}$ was sufficient to meet the greater proportion of crop $\mathrm{N}$ demand at this site (see above). In the $\mathrm{N}$-limited environments (sites 1 and 2), increased biomass in response to $\mathrm{N}$ application in both species and in response to inoculation in soybean was evident by V4 and remained consistently higher than that of unamended crops throughout the crop cycle (Fig. 2). Little additional biomass was accumulated beyond mid-podfill at sites 1 and 2 regardless of treatment or species, with the exception of $\mathrm{N}$ fertilized soybean at site 2, whereas biomass accumulation continued throughout reproductive growth in all treatments in both species at site 3. Crop $\mathrm{N}$ accumulation followed similar patterns (see Fig. I for soybean data).

Treatment effects on seed $\mathrm{N}$ content, crop growth 
Table 3. Average number of nodes on the main stem at given reproductive phase for soybean and bush bean grown under three modes of $\mathrm{N}$ nutrition at four sites on Maui, Hawaii

\begin{tabular}{|c|c|c|c|c|c|c|}
\hline \multirow{2}{*}{$\begin{array}{l}\text { Legume } \\
\text { species }\end{array}$} & \multirow{2}{*}{$\begin{array}{l}\text { Site } \\
\text { No. }\end{array}$} & \multirow{2}{*}{$\begin{array}{l}\mathrm{N} \text { source } \\
\text { treatment }\end{array}$} & \multicolumn{4}{|c|}{ Number of nodes on the main stem } \\
\hline & & & $\mathbf{R} 2$ & R4 & . $\mathbf{R 6}$ & R7 \\
\hline \multirow[t]{12}{*}{ G. $\max$} & \multirow[t]{3}{*}{1} & Unamended & 4.0 & 7.3 & 7.5 & 7.5 \\
\hline & & Inoculated & 5.0 & 8.8 & 10.0 & 10.5 \\
\hline & & N Fertilized & 5.0 & 9.3 & 11.8 & 12.0 \\
\hline & \multirow[t]{3}{*}{2} & Unamended & 4.3 & 5.5 & 7.5 & 7.8 \\
\hline & & Inoculated & 5.0 & 7.3 & 10.0 & 10.3 \\
\hline & & N Fertilized & 5.5 & 8.5 & 10.5 & 10.8 \\
\hline & \multirow[t]{3}{*}{3} & Unamended & 5.0 & 6.5 & 8.3 & 8.3 \\
\hline & & Inoculated & 5.3 & 6.8 & 8.5 & 8.5 \\
\hline & & N Fertilized & 5.3 & 6.3 & 8.3 & 8.3 \\
\hline & \multirow[t]{3}{*}{4} & Unamended & 5.5 & 7.3 & 9.3 & 10.3 \\
\hline & & Inoculated & 6.0 & 7.5 & 10.8 & 12.5 \\
\hline & & N Fertilized & 6.5 & 9.8 & 12.3 & 14.0 \\
\hline \multirow[t]{12}{*}{ P. vulgaris } & \multirow[t]{3}{*}{1} & Unamended & 5.0 & 6.0 & 6.0 & 6.0 \\
\hline & & Inoculated & 6.0 & 7.0 & 7.0 & 7.0 \\
\hline & & N Fertilized & 6.0 & 7.0 & 7.0 & 7.0 \\
\hline & \multirow[t]{3}{*}{2} & Unamended & 5.0 & 6.0 & 6.0 & 6.0 \\
\hline & & Inoculated & 6.0 & 6.0 & 6.0 & 6.0 \\
\hline & & N Fertilized & 6.0 & 7.0 & 7.0 & 7.0 \\
\hline & \multirow[t]{3}{*}{3} & Unamended & 4.0 & 5.0 & 6.0 & 6.0 \\
\hline & & Inoculated & 4.0 & 5.0 & 6.0 & 6.0 \\
\hline & & N Fertilized & 4.0 & 5.0 & 6.0 & 6.0 \\
\hline & \multirow[t]{3}{*}{4} & Unamended & 5.0 & 5.0 & 5.0 & 5.0 \\
\hline & & Inoculated & 6.0 & 6.0 & 6.0 & 6.0 \\
\hline & & N Fertilized & 6.0 & 6.0 & 6.0 & 6.0 \\
\hline
\end{tabular}

rate (CGR), and nitrogen assimilation rate (NiAR), closely resembled those of biomass accumulation in both species (Table 4). However, CGR and MAR varied in relation to the stage of crop development and these patterns differed significantly between the $\mathrm{N}$ source treatments in soybean (data not shown). In general, the period of most rapid growth and $\mathrm{N}$ assimilation in $\mathrm{N}$ fertilized and symbiotic soybean was during early pod-fill, whereas growth rate and MAR were highest at flowering for unamended, nonnodulating plants. In bush bean, NiAR was mainly highest at flowering and CGR highest from flowering to early pod-fill. These patterns tended to be similar for all treatments. In general, differences in growth between uninoculated and inoculated bush bean were minimal most likely as a result of
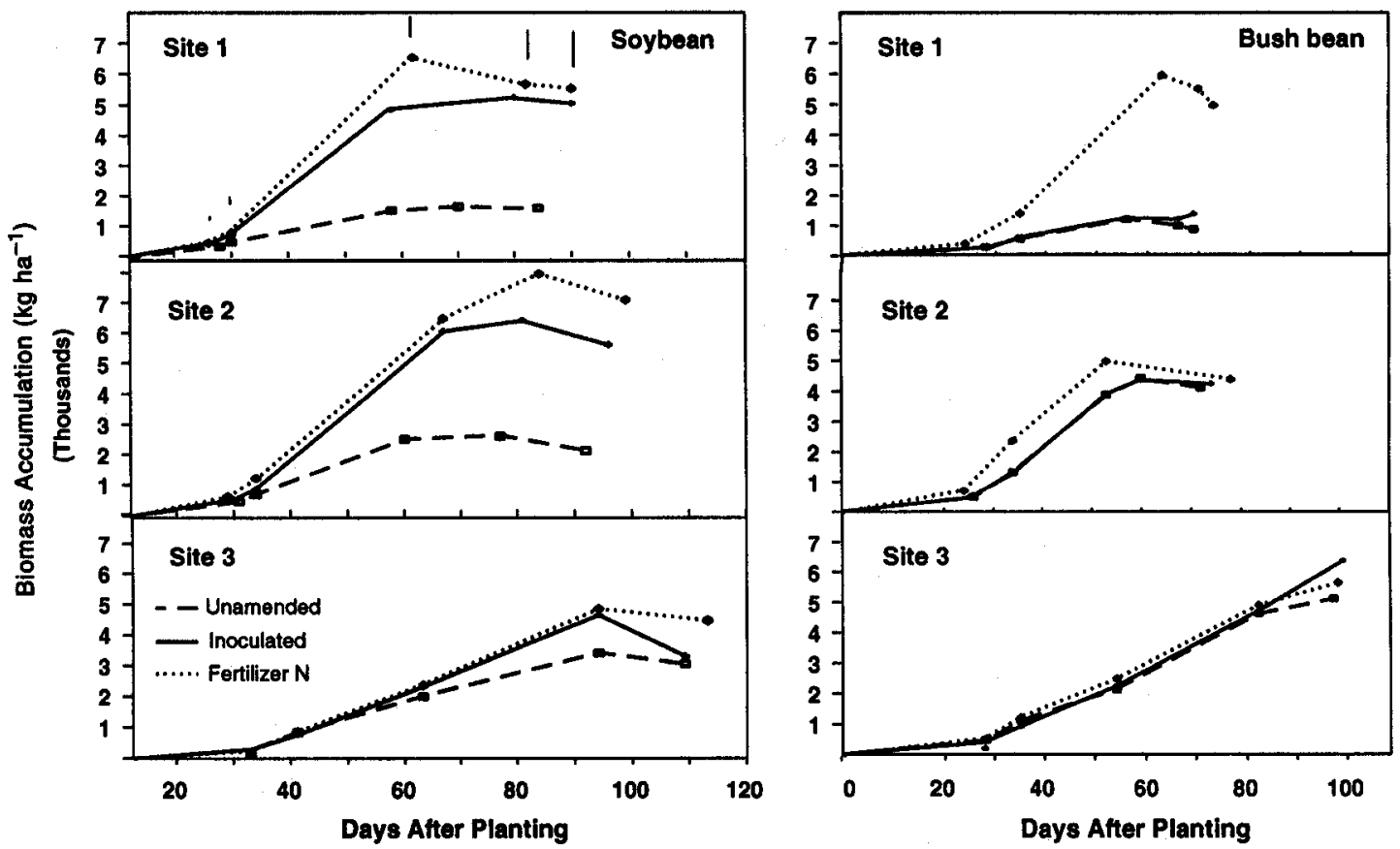

Fig. 2. Biomass accumulation for soybean and bush bean grown under three modes of $\mathrm{N}$ nutrition at three sites on Maui, Hawaii. Bars in the first panel represent LSD values for treatment comparisons. 


\begin{tabular}{|c|c|c|c|c|c|c|c|c|}
\hline $\begin{array}{l}\text { Legume } \\
\text { species }\end{array}$ & $\begin{array}{l}\text { Site } \\
\text { No. }\end{array}$ & $\begin{array}{l}\mathrm{N} \text { source } \\
\text { treatment }\end{array}$ & $\begin{array}{l}\text { Seed } \\
\text { yield } \\
\text { (kgha') }\end{array}$ & $\begin{array}{l}\text { Seed } \\
N\end{array}$ & $\begin{array}{l}\text { CGR I } \\
\text { (kgha' day' }\end{array}$ & $\begin{array}{l}\text { MAR } \\
\left.y^{\prime}\right)\end{array}$ & $\mathrm{HI}$ & $\mathrm{N}(\mathrm{HI})$ \\
\hline \multirow{12}{*}{ G. max } & 1 & Unamended & 627 & 27 & 24 & $\frac{1}{0.41}$ & 0.35 & 0.82 \\
\hline & & Inoculated & 3025 & 177 & 66 & 204 & 0.59 & 0.93 \\
\hline & & N Fetilized & 3024 & 163 & 70 & 204 & 0.54 & 0.91 \\
\hline & 2 & Unamended & 935 & 42 & 34 & 0.64 & 0.42 & 0.84 \\
\hline & & Inoculated & 2782 & 166 & 80 & 263 & 0.50 & 0.82 \\
\hline & & NFertilized & 3125 & 179 & 95 & 280 & 0.44 & 0.79 \\
\hline & 3 & Unamended & 1356 & 73 & 37 & 1.10 & 0.44 & 0.75 \\
\hline & & Inoculated & 1233 & 74 & 50 & 1.54 & 0.37 & 0.64 \\
\hline & & N Fertilized & 1983 & 109 & 52 & 1.69 & 0.44 & 0.69 \\
\hline & 4 & Unamended & 1711 & 83 & 46 & 1.22 & 0.42 & 0.76 \\
\hline & & Inoculated & 3686 & 221 & 71 & 2.83 & 0.56 & 0.84 \\
\hline & & N Fettilized & 4596 & 279 & 91 & 3.58 & 0.51 & 0.79 \\
\hline \multirow[t]{12}{*}{ P. vulganis } & 1 & Unamended & 400 & 11 & 16 & 0.24 & 0.45 & 0.65 \\
\hline & & Inoculated & 731 & 20 & 19 & 0.30 & 0.52 & 0.74 \\
\hline & & N Fertilized & 2891 & 100 & 79 & 1.82 & 0.58 & 0.79 \\
\hline & 2 & Unamended & 2198 & 57 & 74 & 1.81 & 0.55 & 0.77 \\
\hline & & Inoculated & 2316 & 60 & 73 & 1.44 & 0.54 & 0.78 \\
\hline & & NFertilized & 2840 & 96 & 93 & 1.83 & 0.48 & 0.72 \\
\hline & 3 & Unamended & 2625 & 71 & 56 & 1.37 & 0.50 & 0.67 \\
\hline & & Inoculated & 3035 & 82 & 57 & 1.38 & 0.47 & 0.63 \\
\hline & & NFertilized & 2694 & 81 & 60 & 1.75 & 0.48 & 0.60 \\
\hline & 4 & Unamended & 2622 & 70 & 83 & 1.40 & 0.48 & 0.77 \\
\hline & & Inoculated & 3489 & 101 & 97 & 1.96 & 0.53 & 0.76 \\
\hline & & NFertilized & 3868 & 128 & 105 & 2.30 & 0.53 & 0.80 \\
\hline LSD & & & 676 & 30 & & & 0.06 & \\
\hline
\end{tabular}

uninoculated bush bean plants being least partially symbiotic at all sites.

There were highly significant differences between sites in all other growth variables by the first harvest and these were maintained throughout crop growth (Fig. 2, Tables 4 and 5). Yield of both crops was greatest at site 4. Despite soil N sufficiency, soybean yielded least at site 3 where temperatures were lowest during crop growth, whereas, low temperature did not strongly affect bush bean yield (Tables I and 4).

At sites I and 2, where available soil $\mathrm{N}$ was limiting yield, leaf area index (LAI) was increased by inoculation and $\mathrm{N}$ application in soybean as early as the first harvest (V4) (Table 5). LAI was significantly increased in bush bean only in $\mathrm{N}$ fertilized plants. Mode of $\mathrm{N}$ nutrition had minimal effects on specific leaf area (SLA) or leaf weight ratio (LWR) (Table 5).

LWR, SLA and LAI differed significantly between both sites and legume species at the first three harvests (Table 5). For soybean, SLA and LAI were lowest and LWR highest at the coolest site (site 3). This indicated that soybean produced smaller, thicker leaves, relatively more leaves in relation to stem, but less total leaf area, in response to cooler temperature. This may have resulted in reduced photosynthetic capacity which may help to explain the significantly

Table 5. Leaf areaindex, specific leaf area, and leaf weight ratio at given phenological stage of soybean and bush bean grown under three

\begin{tabular}{|c|c|c|c|c|c|c|c|c|c|c|c|c|c|c|}
\hline \multirow[b]{2}{*}{$\begin{array}{l}\text { Legume } \\
\text { species }\end{array}$} & \multirow[b]{2}{*}{$\begin{array}{l}\text { Site } \\
\text { No. }\end{array}$} & \multirow[b]{2}{*}{ N source } & \multicolumn{4}{|c|}{ Leaf areaindex } & \multicolumn{4}{|c|}{ Specific leaf area } & \multicolumn{4}{|c|}{ Leaf weight ratio } \\
\hline & & & V4 & R2 & $\mathrm{R} 5 / 6$ & R7 & V4 & R2 & R5/ 6 & R7 & V4 & R2 & $\mathrm{R} 5 / 6$ & R7 \\
\hline \multirow[t]{9}{*}{ G. $\max$} & $\mathrm{I}$ & Unamended & 0.71 & 0.95 & 1.14 & 0.79 & 373 & 365 & 242 & 216 & 0.56 & 0.53 & 0.30 & 0.20 \\
\hline & & Inoculated & 0.91 & 1.34 & 3.57 & 1.49 & 369 & 359 & 241 & 236 & 0.56 & 0.52 & 0.30 & 0.12 \\
\hline & & N Fentilized & 0.92 & 1.60 & 3.83 & 1.16 & 343 & 355 & 240 & 217 & 0.57 & 0.54 & 0.24 & 0.10 \\
\hline & 2 & Unamended & 0.87 & 1.37 & 2.14 & ND" & 329 & 332 & 226 & $\mathrm{ND}$ & 0.58 & 0.58 & 0.38 & ND \\
\hline & & Inoculated & 1.14 & 1.80 & 3.84 & ND & 351 & 360 & 277 & ND & 0.58 & 0.56 & 0.23 & ND \\
\hline & & N Fentilized & 1.26 & 255 & 406 & ND & 338 & 364 & 253 & ND & 0.59 & 0.56 & 0.25 & ND \\
\hline & 3 & Unamended & 0.54 & 1.40 & 2.18 & 0.88 & 272 & 257 & 225 & 227 & 0.64 & 0.62 & 0.48 & 0.12 \\
\hline & & Inoculated & 0.53 & 1.32 & 2.63 & 1.58 & 257 & 255 & 238 & 171 & 0.65 & 0.62 & 0.47 & 0.20 \\
\hline & & N Fentilized & 0.50 & 1.40 & 2.61 & 0.98 & 271 & 257 & 229 & 178 & 0.65 & 0.62 & 0.48 & 0.12 \\
\hline \multirow[t]{9}{*}{ P. nulganis } & I & Unamended & 0.84 & 1.07 & 0.33 & $\mathrm{ND}$ & 613 & 338 & 99 & ND & 0.51 & 0.55 & 0.26 & ND \\
\hline & & Inoculated & 0.84 & 1.07 & 0.40 & $\mathrm{ND}$ & 498 & 317 & 126 & ND & 0.58 & 0.57 & 0.25 & ND \\
\hline & & N Fentilized & 0.90 & 263 & ND & ND & 400 & 356 & ND & ND & 0.56 & 0.52 & ND & ND \\
\hline & 2 & Unamended & 1.29 & 3.07 & 3.30 & 216 & 415 & 416 & 366 & 367 & 0.61 & 0.56 & 0.23 & 0.13 \\
\hline & & Inoculated & 1.25 & 288 & 3.03 & 239 & 424 & 421 & 349 & 371 & 0.61 & 0.54 & 0.22 & 0.15 \\
\hline & & N Fentilized & 1.90 & 5.90 & 417 & 253 & 434 & 463 & 317 & 302 & 0.62 & 0.53 & 0.27 & 0.14 \\
\hline & 3 & Unamended & 1.28 & 269 & 4.23 & 255 & 393 & 397 & 518 & 352 & 0.66 & 0.60 & 0.38 & 0.16 \\
\hline & & Inoculated & 1.08 & 216 & 422 & 247 & 406 & 373 & 475 & 379 & 0.68 & 0.62 & 0.39 & 0.14 \\
\hline & & N Fentilized & 1.36 & 286 & 444 & 248 & 389 & 398 & 489 & 339 & 0.67 & 0.60 & 0.37 & 0.15 \\
\hline LSD & & & 0.25 & 0.63 & 0.56 & 0.56 & 106 & 44 & 25 & 46 & 0.05 & 0.03 & 0.03 & 0.04 \\
\hline
\end{tabular}

"Not determined. 
reduced yields observed in all treatments at this site. Bush bean responded quite differently to lower temperature in that LWR, SLA, and LAI were significantly higher in the cooler environment (site 3 ) by the third harvest. This indicated that more leaves in relation to stem, with a greater leaf area were produced. This may have resulted in enhanced photosynthetic capacity, which when coupled with sufficient soil $\mathrm{N}$, may account for the high yield obtained in all treatments at this site.

While all growth, development, and yield variables differed significantly between sites, the effect of changing mode of $\mathrm{N}$ nutrition on these variables, in $\mathrm{N}$ limited environments, was consistent across sites. Both vegetative and reproductive development in the two crops were affected by the mode of $\mathrm{N}$ nutrition. In general, improved $\mathrm{C}$ and $\mathrm{N}$ nutrition resulted in greater leaf area, increased rate of node production, and extended seed fill duration, which in turn, resulted in significantly increased biomass and seed yield in $\mathrm{N}$ fertilized and symbiotic plants in the $\mathrm{N}$ limited environments.

\section{DISCUSSION}

In these trials, we examined the effect of both source and amount of available $\mathrm{N}$ on legume phenology, growth, and yield of two crop legumes, soybean and bush bean. Sources of $\mathrm{N}$ available to crops were either: soil $\mathrm{N}$ alone (unamended, nonnodulating soybean isoline); soil $\mathrm{N}$ plus fixed $\mathrm{N}$ (uninoculated bush bean and inoculated soybean and bush bean); and soil $\mathrm{N}$ plus high rates of fertilizer $\mathrm{N}$ ( $\mathrm{N}$ fertilized soybean and bush bean). Amount of available $\mathrm{N}$ varied as a function of site (soil $\mathrm{N}$ content) and treatment, with inoculated and $\mathrm{N}$ fertilized plants considered $\mathrm{N}$ sufficient and unamended, non-nodulating soybean considered $\mathrm{N}$ deficient. Planting date and site elevation were varied in these trials to provide differences in both photoperiod and temperature regimes in order to independently test the consistency of any nitrogen effects. In these trials, both source and supply of $\mathrm{N}$ significantly affected crop vegetative and reproductive development and yield.

The influence of nutritional status, specifically that of $\mathrm{N}$, on the timing of developmental stages (crop phenology) is not highly detailed in the literature. Weber (1966) observed that a non-nodulating soybean isoline (T201) reached maturity as much as 3 days earlier than its nodulated counterpart (T202) in soils of the midwest U.S.A. Similarly, George et al. (1990) observed that time to maturity was extended in several cultivars of nodulated soybeans as compared to their non-nodulating counterparts in three Hawaiian soils. They observed a maximum difference of 5 days in time to grain maturity between nodulated and non-nodulating crops. They attributed the later maturity to delayed flowering in symbiotic soybeans, particularly those from higher maturity groups. In these trials, we observed as much as a 10 day increase in the time required for symbiotic soybeans to reach physiological maturity (R7) as compared to their non-nodulating, $\mathrm{N}$-stressed counterparts. However, this increase in time to physiological maturity was attributable to an increase in seed fill duration as time to flowering was not different in the two crops. Little to no differences in time to critical reproductive stages were observed between uninoculated and inoculated bush bean. However, uninoculated bush bean plants were symbiotic, hence not subject to the $\mathrm{N}$ stress experienced by unamended, non-nodulating soybeans. Lack of any difference between these treatments in bush bean strongly suggests that developmental differences observed in soybean can be primarily attributed to differences in plant $\mathrm{N}$ status and that $\mathrm{N}$ stress may be the primary factor responsible for the hastened maturity observed in non-nodulating soybean. These field results support the hypothesis of Sinclair and de Wit (1976), which they tested by use of a simulation model, that increased external $\mathrm{N}$ supply rate in soybean would lengthen the seed development period. And, that increased duration of seed development would result in increased yield. Their hyothesized relationship between seed fill duration and yield is also borne out by results of this study.

Weber (1966) observed that differences in time to maturity of nodulating and nonnodulating soybean were overcome as more $\mathrm{N}$ was applied. However, no differences were observed in time to maturity of nodulated soybean with no $\mathrm{N}$ applied and nonnodulating plants with $150 \mathrm{lb} \mathrm{N} \mathrm{A'} \mathrm{applied} \mathrm{when} \mathrm{grown} \mathrm{under}$ favorable moisture conditions. When grown under moisture stress, the maximum difference in time to maturity observed between these two treatments was 2 days. In their field trials, George and Singleton (1992) noted that $\mathrm{N}$ fertilized soybean matured as much as 5 days later than fully symbiotic plants. Our results are in agreement with the above studies in that we observed as much as a 6 day delay in time to physiological maturity (R7) of $\mathrm{N}$ fertilized soybean as compared to symbiotic plants. In addition, we observed a similar delay in reproductive maturity of $\mathrm{N}$ fertilized bush bean as compared to symbiotic plants. These results are also in agreement with the proposed relationship between increased $\mathrm{N}$ supply and duration of the seed development period (Sinclair and deWit, 1976). However, these combined results support the suggestion that source of nitrogen (inorganic vs fixed), when extent of supply is high, might also influence the timing of reproductive development in crop legumes and that this may be asociated with differences in photosynthate partitioning between crops dependent on these two $\mathrm{N}$ sources. Sinclair and deWit (1976) did not discriminate between sources of $\mathrm{N}$ (inorganic $\mathrm{N}$ assimilation or nitrogen fixation) in their early model. In a later iteration of the model (Sinclair, 1986), sources of $\mathrm{N}$ are distinguished to the extent that plants depend on 
both soil $\mathrm{N}$ and $\mathrm{N}_{2}$ fixation until soil $\mathrm{N}$ supply is estimated to be exhausted, thereafter, $\mathrm{N}_{2}$ fixation becomes the sole external source of N. Metabolic costs associated with these two modes of $\mathrm{N}$ nutrition are, however, still considered to be equal.

Both Sinclair et al. (1987) and Imsande (1989) have reported that soybean is capable of maintaining nitrogen fixation throughout the seed filling period. In our study, this was the case for soybean grown at site 3, but not for plants grown at sites 1 and 2 (Fig. 1). At these sites, the proportional dependence on $\mathrm{N}_{2}$ fixation did not change and little additional $\mathrm{N}$ was accumulated beyond the mid-podfill stage, whereas, $\mathrm{N}$ fertilized soybean continued to accumulate $\mathrm{N}$ throughout the seed filling period at both sites 2 and 3. Although soybean has the genetic capability to continue $\mathrm{N}_{2}$ fixation throughout seed filling, this capability is not always realized under field conditions, even at locations where water, nutrient, and $\mathrm{pH}$ limitations to yield have been alleviated. Data from these trials coupled with the modeling approach of Sinclair (1986) may prove useful in identifying other site variables that impact duration of $\mathrm{N}_{2}$ fixation in the field.

The dramatic effects of poor $\mathrm{N}$ nutrition on legume growth and yield are well-documented so that the reduced number of nodes on the main stem, rates of biomass and $\mathrm{N}$ accumulation, and yield observed in this study for non-nodulating soybean at sites with low soil $\mathrm{N}$ availability are all consistent with effects described elsewhere in the literature for legumes and other crop species. Effects of source of $\mathrm{N}$ (unlimiting inorganic vs fixed) on growth and yield are more infrequently reported and not always consistent. Imsande (1989) reported that soybean receiving excess amounts of mineral $\mathrm{N}$ accumulated less total $\mathrm{N}$ than inoculated, well-nodulated plants. In contrast, it has been observed more frequently that crops receiving high rates of applied mineral $\mathrm{N}$ produce greater yield and accumulate more $\mathrm{N}$ than their symbiotic counterparts (Cassman et al., 1981; Buttery and Stone, 1988; George and Singleton, 1992). Our results agree with the latter reports and indicate there is a real cost, reflected in reduced growth and yield, associated with legumes being symbiotic. This idea is supported by the work of Ryle et al. (1979) who, under controlled conditions, demonstrated that soybeans relying on nitrogen fixation respired 11-13\% more of their fixed carbon each day than plants of equivalent size whose sole source of $\mathrm{N}$ was nitrate.

In summary, soil $\mathrm{N}$ supply limited crop yield in three of the four sites used in our study. At these sites, unamended, non-symbiotic plants had significantly lower leaf area, growth rate, and yield than either $\mathrm{N}_{2}$-fixing or $\mathrm{N}$ fertilized plants. For $\mathrm{N}$ fertilized soybean, extended phenophase duration was observed as early as R4, whereas, in inoculated plants extended phenophase duration was not observed until the later stages of reproductive development (commonly between R5/R6 and R7). Extended phenophase duration in $\mathrm{N}$ fertilized bush bean over that of symbiotic plants was also not observed until the later stages of reproductive development. In general, plants well supplied with $\mathrm{N}$, either through fertilization or $\mathrm{N}_{2}$ fixation, were larger and had a higher number of nodes on the main stem, and consequently, more leaves, pods and seeds, and showed as much as a 10 day increase in seed fill duration over $\mathrm{N}$ deficient plants. While symbiotic plants were found to be more similar in their phenology, growth and yield to those receiving high rates of applied $\mathrm{N}$ than to unamended plants, they were not strictly equivalent. Symbiotic plants accumulated less biomass across the crop cycle, yielded less, and matured somewhat earlier than $\mathrm{N}$ fertilized plants, particularly in cooler environments. The significant differences in crop phenology, growth, and yield observed between the modes of $\mathrm{N}$ nutrition used in this study indicate that legume growth simulation models that do not currently include subroutines capable of integrating the combined effects of source and extent of supply of $\mathrm{N}$ on legume development and yield should consider such subroutines in future versions. Trials reported here provide input data with which to pursue such endeavors. These data have been used already to validate subroutines for inorganic nitrogen assimilation and nitrogen fixation that were developed and incorporated into the SOYGRO model since its last publication (see v5.42, Jones et al., 1989).

Acknowledgements-This research was supported by the National Science Foundation and the United States Agency for International Development Cooperative Agreement (NitTAL Project). We appreciatively acknowledge use of the nonnodulating isoline of G. max ev. Clark IV provided by P. Cregan, USDA Nitrogen Fixation Laboratory, Beltsville, Md, use of the Maui Soil, Climate, and Land Use Network developed by H. Ikawa of the Department of Agronomy and Soil Science, University of Hawaii, and assistance by Geoffrey Haines and Kevin Keane in the field. We are grateful to Professor John S. Pate, Department of Botany, The University of Western Australia, for his helpful review of this manuscript. This paper is Journal Series No. 4031 of the Hawaii Institute of Tropical Agriculture and Human Resources.

\section{REFERENCES}

Buttery B. R. and Stone J. A. (1988) Some effects of nitrate and light intensity on soybean root growth and development. Plant and Soil 106, 291-294.

Cassman K. G., Whitney A. S. and Fox R. L. (1981) Phosphorus requirements of soybean and cowpea as affected by mode of $\mathrm{N}$ nutrition. Agronomy Journal 73, 17-22.

Fehr W. R., Caviness C. E., Burmood D. T. and Pennington J. S. (1971) Stage of development descriptions for soybeans, Glycine $\max ($ L.) Merrill. Crop Science 11, 929-931.

George T. and Singleton P. W. (1992) Nitrogen assimilation traits and dinitrogen fixation in soybean and common bean. Agronomy Journal 84, 1020-1028.

George T., Bartholomew D. P. and Singleton P. W. (1990) Effect of temperature and maturity group on phenology 
of field grown nodulating and nonnodulating soybean isolines. Biotronics 19, 49-59.

Graham P. H. (1981) Some problems of nodulation and symbiotic nitrogen fixation in Phaseolus vulgaris L.: a review. Field Crops Research 4, 93-112.

Hadley P., Roberts E. H., Summerfield R. J. and Minchin F. R. (1984) Effects of temperature and photoperiod on flowering in soya bean [Glycine $\max (\mathrm{L}$.) Merrill]: a quantitative model. Annals of Botany 53, 669-681.

Hodges T. and French V. (1985) Soyphen: soybean growth stages modeled from temperature, daylength and water availability. Agronomy Journal 77, 500-505.

Imsande J. (1988) Interrelationship between plant developmental stage, plant growth rate, nitrate utilization and nitrogen fixation in hydroponically grown soybean. Journal of Experimental Botany 39, 775-785.

Imsande J. (1989) Rapid dinitrogen fixation during soybean pod fill enhances net photosynthetic output and seed yield: a new perspective. Agronomy Journal 81, 549-556.

Jones J. W., Boote K. J., Hoogenboom G., Jagtap S. S. and Wilkerson G. G. (1989) SOYGRO v. 5.42: soybean crop growth simulation model. User's Guide. Florida Agricultural Experiment Station Journal No. 8304, Gainesville, Fla.

Kucey R. M. N. (1989) The influence of rate and time of mineral N application on yield and $\mathrm{N}_{2}$ fixation by field bean. Canadian Journal of Plant Science 69, 427-436.

Lynch J. M. and Wood M. (1988) Interactions between plant roots and micro-organisms. Russell's Soil Conditions and Plant Growth (A. Wild, Ed.), pp. 526-563. 11 th edn. Longman Scientific \& Technical, Harlow.

McIntosh M. S. (1983) Analysis of combined experiments. Agronomy Journal 75, 153-155.

Pate J. S. and Layzell D. B. (1990) Energetics and biological costs of nitrogen assimilation. In Biochemistry of Plants, Vol. 16 (B. J. Miflin and P. J. Lea, Eds), pp. 1-12. Academic Press, San Diego.
Ryle G. J, A., Powell C. E. and Gordon A. J. (1979) The respiratory costs of nitrogen fixation in soyabean, cowpea, and white clover. II. Comparisons of the cost of nitrogen fixation and the utilization of combined nitrogen. Journal of Experimental Botany 30, 145-153.

SAS Institute (1986) SAS User's Guide: Statistics. SAS Institute Inc., Cary.

Silsbury J. H. (1977) Energy requirement for symbiotic nitrogen fixation. Nature 267, 149-150.

Sinclair T. R. (1986) Water and nitrogen limitations in soybean grain production. I. Model development. Field Crops Research 15, 125-141.

Sinclair T. R. and de Wit C. T. (1976) Analysis of the carbon and nitrogen limitations to soybean yield. Agronomy Journal 68, 319-324.

Sinclair T. R., Muchow R. C., Ludlow M. M., Leach G. J., Lawn R. J. and Foale M. A. (1987) Field and model analysis of the effect of water deficits on carbon and nitrogen accumulation by soybean, cowpea, and black gram. Field Crops Research 17, 121-140.

Soil Conservation Service (1984) Soil survey, laboratory data, and descriptions for some soils of MauiNet, Soil Conservation Service, USDA, Washington.

Summerfield R. J., Dart P. J., Huxley P. A., Eaglesham A. R. J., Minchin F. R. and Day J. M. (1977) Nitrogen nutrition of cowpea (Vigna unguiculata). I. Effects of applied nitrogen and symbiotic nitrogen fixation on growth and seed yield. Experimental Agriculture 13, 129-142.

Thies J. E., Singleton P. W. and Bohlool B. B. (1991) Influence of the size of indigenous rhizobial populations on establishment and symbiotic performance of introduced rhizobia on field-grown legumes. Applied \& Environmental Microbiology 57, 19-28.

Weber C. R. (1966) Nodulating and nonnodulating soybean isoline: I. Agronomic and chemical attributes. Agronomy Journal 58, 43-16. 